University of Nebraska - Lincoln

DigitalCommons@University of Nebraska - Lincoln

2013

\title{
Adaptation to Climate Change: Changes in Farmland Use and Stocking Rate in the U.S.
}

Jianhong E. Mu

Texas A\&M University, mujh1024@gmail.com

Bruce A. McCarl

Texas A\&M University

Anne W. Wein

U.S. Geological Survey

Follow this and additional works at: https://digitalcommons.unl.edu/usgsstaffpub

Mu, Jianhong E.; McCarl, Bruce A.; and Wein, Anne W., "Adaptation to Climate Change: Changes in Farmland Use and Stocking Rate in the U.S." (2013). USGS Staff -- Published Research. 743.

https://digitalcommons.unl.edu/usgsstaffpub/743

This Article is brought to you for free and open access by the US Geological Survey at DigitalCommons@University of Nebraska - Lincoln. It has been accepted for inclusion in USGS Staff -- Published Research by an authorized administrator of DigitalCommons@University of Nebraska - Lincoln. 


\title{
Adaptation to climate change: changes in farmland use and stocking rate in the U.S.
}

\author{
Jianhong E. Mu • Bruce A. McCarl • Anne M. Wein
}

Received: 3 January 2012 / Accepted: 11 April 2012 / Published online: 24 May 2012

(C) Springer Science+Business Media B.V. 2012

This article is a U.S. government work, and is not subject to copyright in the United States.

\begin{abstract}
This paper examines possible adaptations to climate change in terms of pasture and crop land use and stocking rate in the United States (U.S.). Using Agricultural Census and climate data in a statistical model, we find that as temperature and precipitation increases agricultural commodity producers respond by reducing crop land and increasing pasture land. In addition, cattle stocking rate decreases as the summer Temperature-humidity Index (THI) increases and summer precipitation decreases. Using the statistical model with climate data from four General Circulation Models (GCMs), we project that land use shifts from cropping to grazing and the stocking rate declines, and these adaptations are more pronounced in the central and the southeast regions of the U.S. Controlling for other farm production variables, crop land decreases by $6 \%$ and pasture land increases by $33 \%$ from the baseline. Correspondingly, the associated economic impact due to adaptation is around -14 and 29 million dollars to crop producers and pasture producers by the end of this century, respectively. The national and regional results have implications for farm programs and subsidy policies.
\end{abstract}

Keywords Adaptation - Climate change $\cdot$ Land use $\cdot$ Stocking rate $\cdot$ Fractional multinomial logit model $\cdot$ Climate projection $\cdot$ Economic impacts

\section{Introduction}

In the United Nations Intergovernmental Panel on Climate Change (IPCC) fourth assessment report (2007a), climate change is predicted to increase temperatures, and alter precipitation and water supply patterns. It appears that a substantial degree of this change is inevitable and is expected to change agricultural productivity and to shift ecosystems poleward or to higher

J. E. $\mathrm{Mu}(\bowtie) \cdot$ B. A. McCarl

Department of Agricultural Economics, Texas A\&M University, College Station, TX 77840, USA e-mail: mujh1024@gmail.com

A. M. Wein

Western Geographic Science Center, U.S. Geological Survey, Menlo Park, CA 94025, USA 
altitudes (Neilson et al. 2005). These shifts will cause some ecosystems to expand and others to shrink (Mendelsohn and Dinar 2009). Specifically, warming is likely to increase the productivity of crops relative to livestock in cool places but reduce crop productivity in relatively hot locations. Thus, adaptation strategies are likely necessary (Rose and McCarl 2008). In fact, adaption is nothing new for agriculture as producers have already adapted to local climate changes (Herrero et al. 2008; McCarl 2007; Hoffmann 2010).

Studies have considered climate effects on crop production, livestock production, and both (IPCC 2007b; Hahn et al. 2005; Mader et al. 2009; U.S. Climate Change Science Program 2008; Jones and Thornton 2009). With climate change, land use changes are expected to occur among agricultural enterprises (Adams et al. 1990; Zilberman et al. 2004). For example, as climate becomes hotter and wetter, African farmers are likely to increase joint production of crops and animals (Seo 2010). A hot and dry climate in Africa is expected to favor livestock over crop production in high elevation areas (Seo et al. 2009) and livestock ownership is likely to decline as the climate becomes wetter (Seo and Mendelsohn 2008a, b).

However, few studies have examined adaptation to climate change via farmland use change and livestock stocking rate adjustment, in particular. It is well known that climate change effects are not uniformly distributed, some regions may gain and others may lose. Thus, better understanding of the effects of climate change adaptations on the welfare distributions is important information for farm programs and subsidy policies. The purpose of this paper is to examine U.S. adaptation possibilities in terms of livestock and crop land use change and livestock stocking rate change. We do this using a Fractional Multinomial Logit (FMLOGIT) model to estimate the effects of climate variables on land use shares and a Ordinary least squares (OLS) regression to examine livestock stocking rate. Based on our statistical results, we project adaptation to climate change scenarios from the 2007 IPCC report and evaluate the economic impacts of these adaptation strategies.

\section{Material and methods}

\subsection{Data}

Data for this study include crop, pasture and total farmland acres, livestock stocking rate, climate and social-economic variables. Our sources of agricultural data are the Census of Agriculture and the U.S. Department of Agriculture (USDA). The data are available by crop reporting districts from 1987 to $2007^{1}$ at five-year intervals - the time gap between observations is long enough to allow land use change and stocking rate change. From the acreage data, we derive the percent share of crop land and pasture land in each crop reporting district.

The stocking rate (SR) is the number of animals on a unit of land over a certain period of time (Redfearn and Bidwell 2011). Such data are not readily available. Consequently, we construct it. We develop a district level number of equivalent animals based on the Animal Unit Month (AUM) concept, which normalizes populations based on the amount of forage required. We do this across the annual inventory of beef cows and milk cows, beef cow replacements, milk cow replacements, and calves in each crop reporting district using data from the USDA National Agriculture Statistics Service (NASS). In particular, following Redfearn and Bidwell (2011) and Pratt and Rasmussen (2001), ${ }^{2}$ we assume that AUM conversion factors for milk cows, replacements of beef and milk cows, and calves are 1.5,

\footnotetext{
${ }^{1}$ The Census of Agriculture reports come out each 5 years, so 2007 is the most recent report available.

${ }^{2}$ See Pratt and Rasmussen (2001) for definition and calculation of the stocking rate for each animal.
} 
$0.7,0.8$, and 0.6 , respectively. Hence, the stocking rate for cattle in the ith crop-reporting district is calculated as follows,

$$
S R_{i}=\frac{\sum_{k} A U E_{i k} * \text { Inventory }_{i k}}{\text { Pastureland }_{i}}
$$

where $A U E_{i k}$ and Inventory ${ }_{i k}$ is the Animal Unit Equivalent and the number of $k$ th animals, respectively; $k=$ beef cows, milk cows, replacement of beef cows, replacement of milk cows, and calves, and Pastureland ${ }_{i}$ is the total acreage of pasture land for grazing use.

Climate variables include seasonal mean temperature and total precipitation for the 3 years preceding each census year ${ }^{3}$ from the National Climatic Data Center (NCDC). Temperature is measured in degrees Fahrenheit $\left({ }^{\circ} \mathrm{F}\right)$ and the total precipitation is measured in inches. We also include other variables that represent extreme climate conditions. In particular,

- A temperature-humidity index (THI) is computed using the formula developed by Dikmen and Hansen (2009), ${ }^{4}$ where values above the threshold of 79 are harmful for livestock gaining weight;

- A Palmer drought index is drawn from the NCDC, where values below -4 reflect extreme drought and those above +4 indicate extreme wetness;

- The number of hot days when maximum temperatures are higher than $90^{\circ} \mathrm{F}$ during a season are counted to indicate extreme heat.

- An index of precipitation intensity (preint) computed following IPCC (2007a), is the percent of annual total precipitation due to events exceeding the 95 th percentile. The 95th percentile is derived from ranking all daily precipitation between 1961-1990. For each year, we sum the daily precipitation that exceeds the 95 th percentile using a ranked list of daily precipitation from the smallest to largest value. The equation for calculating the precipitation index is, preint $=\frac{\text { (total annual precipitation that exceed } 95 \text { th percentile }) * 100}{\text { total annual precipitation }}$

We also incorporate other economic and geographic variables including market values of crop and livestock products (both in $\$ 1,000$ ), and dummy indicators of market regions with sub-region 6 as the reference point (see Table 1).

The total dataset contains observations for five census years amounting to 1,034 observations in total. The share of crop and pasture land area account for over $90 \%$ of total farmland in most crop reporting districts. Currently, crop and pasture land shares are $58 \%$ and $31 \%$ of the total farmland, respectively, and the average stocking rate is 0.35 animals per acre. Table 2 displays the statistical characteristics of the variables used in this study.

\subsection{Theoretical model}

Following Seo et al. (2010), the impacts of climate on farmland use share can be measured by examining how the probability of land use for cropping versus pasture varies as a function of climate variables. Controlling for all other factors, if land use in cropping is less profitable than land use in pasture, farmers would prefer using land for livestock production, which translates into a smaller probability for cropping and a larger one for pasture use.

\footnotetext{
${ }^{3}$ For example, when the dependent variable in our model is from 1987, we use the seasonal averaged climate over 1985-1987, and similarly with the other four agricultural census data.

$4 T H I=0.8 * T a+(R H / 100) *(T a-14.3)+46.4$, where $R H=(6.1121) * e^{\wedge}(18.678-T a / 234.5) \times$ $(T a /(257.14+T a))$ and $T a=$ temperature in ${ }^{\circ} \mathrm{C}$ and $R H$ is the relative humidity. When we construct the $\mathrm{THI}$ index, we convert our temperature data in to Celsius degree.
} 
Table 1 Definition of market and production regions in the U.S.

\begin{tabular}{lll}
\hline Region Dummy & Market Region & Production Region \\
\hline 1 & Corn (Zea) Belt (CB) & Illinois, Indiana, Iowa, Missouri and Ohio \\
2 & Great Plains (GP) & Kansas, Nebraska, North Dakota and South Dakota \\
3 & Lake States (LS) & Michigan, Minnesota and Wisconsin \\
4 & North East (NE) & $\begin{array}{l}\text { Maryland, New Jersey, New York, Pennsylvania, Vermont } \\
\text { and West Virginia }\end{array}$ \\
5 & Rocky Mountains (RM) & $\begin{array}{l}\text { Arizona, Colorado, Idaho, Montana, Nevada, New Mexico, } \\
\text { Utah and Wyoming }\end{array}$ \\
6 & Pacific Southwest (PSW) & California \\
7 & Pacific Northwest (PNW) & Oregon and Washington \\
8 & South Central (SC) & Kentucky, Tennessee, Alabama, Arkansas, Louisiana, \\
& & Mississippi \\
9 & South East (SE) & Virginia, North Carolina, South Carolina, Florida and Georgia \\
10 & South West (SW) & Oklahoma and Texas \\
\hline
\end{tabular}

The 10 market regions provide a consolidation of regional definitions. Forestry production is included in 8 of the market regions (all but Great Plains and Southwest), whereas agricultural production is included in all of the market regions. The Great Plains and Southwest regions are separated to reflect important differences in agricultural characteristics

Theoretically, change in land use between crop and pasture can be described by Fig. 1. The $L$ is the total farmland which is assumed fixed, and from left to right shows the land allocated to crops, thus, the rest is pasture land use. The two sloped lines are the marginal returns to land allocated to crops and pasture, $P_{L}$ is the land price; $L_{1}$ is the land allocated to crops and $L-L_{1}$ is the land allocated to pasture under current conditions. With climate change, the returns to crop and pasture are represented as dash lines and $L_{2}, L-L_{2}$ is the land allocation for crop and pasture under climate change, respectively. In this case, substitution occurs between crop and pasture land use when productivity and returns shift differentially.

\subsection{Econometric models for land use shares}

Land use for crop and pasture can be computed in terms of proportional shares, which fall between zero and one. Under this limited range of values, traditional estimation methods (linear regression, general linear method, etc.) are not appropriate (Ramalho et al. 2011). We employ the estimation method developed by Papke and Wooldridge (1996; 2008), who introduce a quasi-maximum likelihood estimator (QMLE) to obtain a robust method to estimate fractional response models without an ad hoc transformation of boundary values (Ramalho et al. 2011).

Thus, the conditional mean model for land share is assumed to be $E\left[l_{i j} \mid x_{i}\right]=G_{j}\left(\beta, x_{i}\right)$, where $l s_{i j}$ is the proportional share for the $j$ th land use in the $i t h$ crop reporting district; $\beta$ are parameters to be estimated and $x_{i}$ are explanatory variables listed in Table 2, including climate conditions, extreme events and social-economic characteristics. Following Koch (2010), keeping $l s_{i j}$ within the unit interval $[0,1]$ can be accomplished by assuming the multinomial logit functional form for $G_{j}\left(\beta, x_{i}\right)$, such that the conditional distribution of land share among $\mathrm{M}$ farmland uses is given as,

$$
E\left[l s_{i j} \mid x_{i}\right]=G_{j}\left(\beta, x_{i}\right)=\frac{\exp \left(x_{i} \beta_{j}\right)}{\sum_{m=1}^{M} \exp \left(x_{i} \beta_{m}\right)} \quad j=1,2, \ldots, \mathrm{M}
$$


Table 2 Statistical characteristics of variables used in the econometric model

\begin{tabular}{|c|c|c|c|c|}
\hline Variable & Mean & Std. Dev. & Min & Max \\
\hline Percent of crop land (\%) & 0.58 & 0.24 & 0.00 & 0.96 \\
\hline Percent of pasture land (\%) & 0.31 & 0.24 & 0.01 & 0.98 \\
\hline Stocking rate (\# of animal per acre) & 0.35 & 0.41 & 0 & 5.67 \\
\hline Spring precipitation(inch) & 9.32 & 4.46 & 0.12 & 37.57 \\
\hline Squared spring precipitation & 106.78 & 107.11 & 0.01 & 1411.51 \\
\hline Summer precipitation(inch) & 10.97 & 4.84 & 0.04 & 33.47 \\
\hline Squared summer precipitation & 143.62 & 117.86 & 0.00 & 1120.24 \\
\hline Winter precipitation(inch) & 8.69 & 5.76 & 0.27 & 44.99 \\
\hline Squared winter precipitation & 108.63 & 156.70 & 0.07 & 2024.10 \\
\hline Spring temperature $\left({ }^{\circ} \mathrm{F}\right)$ & 53.07 & 8.51 & 32.07 & 73.80 \\
\hline Squared spring temperature & 2889.14 & 909.93 & 1028.49 & 5446.44 \\
\hline Summer temperature $\left({ }^{\circ} \mathrm{F}\right)$ & 72.83 & 5.77 & 57.77 & 85.80 \\
\hline Squared summer temperature & 5337.35 & 837.88 & 3337.37 & 7361.64 \\
\hline Winter temperature $\left({ }^{\circ} \mathrm{F}\right)$ & 34.82 & 10.85 & 6.53 & 64.53 \\
\hline Squared winter temperature & 1330.17 & 777.09 & 42.64 & 4164.12 \\
\hline Spring Palmer drought index & 0.19 & 2.19 & -7.35 & 6.72 \\
\hline Summer Palmer drought index & 0.06 & 2.29 & -9.47 & 9.37 \\
\hline Winter Palmer drought index & 0.63 & 1.75 & -5.48 & 5.98 \\
\hline Precipitation intensity index & 0.17 & 0.10 & 0.00 & 0.70 \\
\hline Number of hot days with temp $>90^{\circ} \mathrm{F}$ & 29.42 & 27.83 & 0.00 & 125.00 \\
\hline Logged market value of crop products $(1,000 \$)$ & 12.30 & 1.38 & 7.92 & 16.12 \\
\hline Logged market value of livestock products $(1,000 \$)$ & 12.39 & 1.17 & 8.47 & 16.71 \\
\hline Summer temperature-humidity index & 67.89 & 3.43 & 62.02 & 77.39 \\
\hline Winter temperature-humidity index & 61.98 & 0.21 & 61.92 & 64.25 \\
\hline Year $=1992$ & 0.19 & 0.39 & 0 & 1 \\
\hline Year $=1997$ & 0.20 & 0.40 & 0 & 1 \\
\hline Year $=2002$ & 0.18 & 0.39 & 0 & 1 \\
\hline Year $=2007$ & 0.23 & 0.42 & 0 & 1 \\
\hline Observation & 1034 & & & \\
\hline
\end{tabular}

Fig. 1 Theoretical model of land use change under climate change

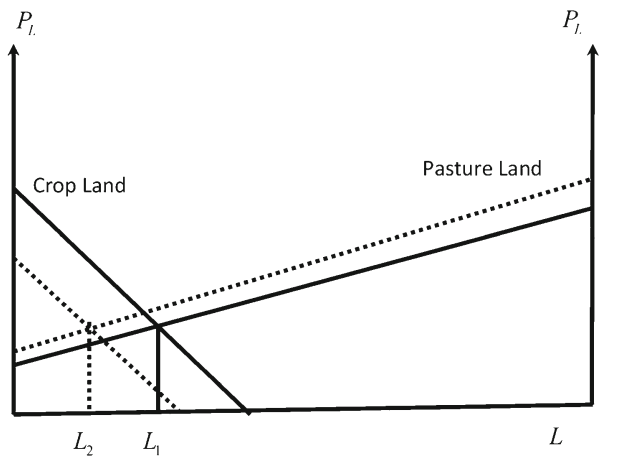


Some normalization is required for Eq. (1) because not all cases of $\beta_{j}$ will be separately identified in the multinomial quasi-likelihood function (Mullahy 2010). Thus, $\beta_{M}=0$ is used. Then the estimation function is given by,

$$
E\left[l_{i j} \mid x_{i}\right]=\frac{\exp \left(x_{i} \beta_{j}\right)}{1+\sum_{m=1}^{M-1} \exp \left(x_{i} \beta_{m}\right)} \quad j=1,2, \ldots, \mathrm{M}-1
$$

and

$$
E\left[l s_{i M} \mid x_{i}\right]=\frac{1}{1+\sum_{m=1}^{M-1} \exp \left(x_{i} \beta_{m}\right)}
$$

Together with Eqs. (2) and (3), the conditional distribution of land share also enforces Eqs. (4) and (5) and accommodates Eqs. (6) and (7) for $j=1,2, \ldots, \mathrm{M}$

$$
\begin{aligned}
& E\left[l s_{i j} \mid x_{i}\right] \in(0,1) \\
& \sum_{m=1}^{M} E\left[l s_{i m} \mid x_{i}\right]=1 \\
& \operatorname{Pr}\left(l s_{i j}=0 \mid x_{i}\right) \geq 0 \\
& \operatorname{Pr}\left(l s_{i j}=1 \mid x_{i}\right) \geq 0
\end{aligned}
$$

Assuming the functional form of the conditional mean model is correct and following Gourieroux et al. (1984) and Mullahy (2010), we estimate a quasi-maximum likelihood (QML) function simultaneously and efficiently. Examples of applications of this method can be found in Mullahy and Robert (2010), Koch (2010), and Mullahy (2010), as well as in the transportation research literature (Ye et al. 2005).

Given the estimation results, our focus is on average partial effects (APE), which is the effect of a change in one of the explanatory variables on the land use shares (as in Mullahy and Robert 2010). Partial effects can be calculated from Eq. (1) directly depending upon whether the variable of interest is discrete or continuous. Suppose $x_{i l}$ is a continuous variable, then the partial effect of a change in share $l s_{i j}$ is the derivative of the expected conditional mean,

$$
\frac{\partial E\left[l s_{i j} \mid x_{i}\right]}{\partial x_{i l}}=\beta_{j l} G_{j}-G_{j} \sum_{m=1}^{M-1} G_{m} \beta_{m l}
$$

Similarly, if $x_{i l}$ is a dummy variable, the partial effect is a ratio of the differences of the expected conditional mean and the change in $x_{i l}$,

$$
\frac{\Delta E\left[l_{i j} \mid x_{i}\right]}{\Delta x_{i l}}=\left.G_{j}\left(\beta, x_{i}\right)\right|_{x_{i l=1}}-\left.G_{j}\left(\beta, x_{i}\right)\right|_{x_{i l=0}}
$$


Given Eqs. (8) and (9), APEs can be calculated after estimation, and their corresponding standard errors are computed using delta methods.

\subsection{Econometric models for stocking rate}

Livestock stocking rate also may be affected by climate. According to Redfearn and Bidwell (2011), maximum animal performance occurs at light stocking rates because there is little competition for the best forage plants in the pasture. Furthermore, they state that the number of animals that can be placed on a particular piece of land depends on the forage supply with lower supplies lowering the stocking rate. As stocking rate increases, individual animal performance is reduced due to increased competition and the total amount of weight gain produced per acre increases up to a threshold and then declines. Implicit in these observations is a climate effect on stocking rate via the climate effect on forage growth. Therefore, we estimate livestock stocking rate as a quadratic function of seasonal temperature and precipitation.

The general econometric model for cattle stocking rate is given as,

$$
S R_{i}=f\left(\alpha, z_{i}\right)
$$

where $\mathrm{z}_{i}$ presents a vector of explanatory variables affecting cattle stocking rate in the ith crop reporting district and $\alpha$ are the corresponding coefficients. To check whether climate variables have different influences on the various quantiles of stocking rate, we employ the Ordinary Least Square (OLS) regression and Quantile regression to estimate climate effects on cattle stocking rate.

\section{Empirical results}

\subsection{Land use shares and climate}

Now, we turn to the empirical results of the econometric model with three farmland uses of cropping, grazing and other (i.e., $\mathrm{M}=3$ ) and model robustness tests. We report results with and without regional effects. Due to the interaction and squared terms, the signs and magnitudes of the individual estimated coefficients in Table 6 do not fully represent the effects of each climate phenomenon. Therefore,we derive the true marginal effects of temperature and precipitation by calculating the average partial effects.

Table 3 reports average partial effects of explanatory variables on land use shares. In most cases, these results have opposite signs for cropping and livestock grazing land uses reflecting land competition and substitution. Temperature results indicate that spring and summer temperatures have statistically significant impacts on land use allocation. In the spring, crop land increases with warmer temperature. However, in the summer, we see that increases in summer temperature are associated with increased share of livestock land use. Additionally, an increase in the number of summer hot days relates to a land use shift into livestock, consistent with findings that extreme heat is harmful for crop yields (Schlenker et al. 2005, 2006; Schlenker and Roberts 2006) and forage yields are less sensitive than crop yields (Holden and Brereton 2002).

The Palmer drought index can be used to investigate long term drought effects on crop and pasture land use. The probability of pasture land increases when summer droughts 
Table 3 Partial average effects from FMLOGIT with and without regional effects

\begin{tabular}{|c|c|c|c|c|}
\hline & \multicolumn{2}{|c|}{ Model with Market Region Effects } & \multicolumn{2}{|c|}{ Model without Market Region Effects } \\
\hline & Cropland & Pastureland & Cropland & Pasture land \\
\hline Corn Belt (CB) & $0.2583(0.5309)$ & $-0.2141(0.6626)$ & & \\
\hline Great Plains (GP) & $0.2246(0.4470)$ & $-0.1400(0.4312)$ & & \\
\hline Lake States (LS) & $0.2194(0.6922)$ & $-0.2479(0.8364)$ & & \\
\hline North East (NE) & $0.1596(0.5494)$ & $-0.1992(0.6441)$ & & \\
\hline Rocky Mountains (RM) & $0.0467(0.1025)$ & $-0.0451(0.1211)$ & & \\
\hline Pacific Northwest (PNW) & $0.1088(0.1915)$ & $-0.0701(0.2057)$ & & \\
\hline South Central (SC) & $0.1963(0.3617)$ & $-0.1510(0.4484)$ & & \\
\hline South East (SE) & $0.0953(0.3598)$ & $-0.1340(0.3949)$ & & \\
\hline South West (SW) & $0.0095(0.0803)$ & $-0.0131(0.0701)$ & & \\
\hline Spring precipitation & $-0.0031 * * *(0.0012)$ & $0.0064 * * *(0.0017)$ & $-0.0071^{* * *}(0.0023)$ & $0.0115^{* * *}(0.0027)$ \\
\hline Summer precipitation & $-0.0099 * * *(0.0036)$ & $0.0069 * * *(0.0028)$ & $-0.0176^{* * *}(0.0062)$ & $0.0122 * * *(0.0045)$ \\
\hline Winter precipitation & $-0.0104 * * *(0.0037)$ & $0.009 * * *(0.0029)$ & $-0.01 * * *(0.0034)$ & $0.0076^{* * *}(0.0026)$ \\
\hline Spring temperature & $0.0142 * * *(0.0049)$ & $-0.0136 * * *(0.004)$ & $0.0191 * * *(0.0066)$ & $-0.0136^{* * *}(0.0049)$ \\
\hline Summer temperature & $-0.0161 * * *(0.0056)$ & $0.0158 * * *(0.0045)$ & $-0.0223 * * *(0.0073)$ & $0.0217 * * *(0.0059)$ \\
\hline Winter temperature & $-0.0006(0.0005)$ & $-0.0014 * *(0.0008)$ & $0.0012(0.0012)$ & $-0.0068^{* * *}(0.002)$ \\
\hline Spring Palmer drought index & $-0.0024(0.0069)$ & $0.0023(0.0076)$ & $0.0019(0.0073)$ & $-0.0084(0.0077)$ \\
\hline Summer Palmer drought index & $-0.0218 * * *(0.0067)$ & $0.0212 * * *(0.0065)$ & $-0.0366^{* * *}(0.0055)$ & $0.0433 * * *(0.0058)$ \\
\hline Winter Palmer drought index & $0.0081 *(0.0062)$ & $-0.0106^{*}(0.0070)$ & $0.0150 * * *(0.0064)$ & $-0.0145^{* *}(0.0071)$ \\
\hline Precipitation intensity index & $0.0077(0.0401)$ & $0.0275(0.0416)$ & $0.0833 * *(0.0455)$ & $-0.0763 *(0.0474)$ \\
\hline $\begin{array}{l}\text { Number of hot days } \\
\text { with temp }>90^{\circ} \mathrm{F}\end{array}$ & $-0.0017 * * *(0.0006)$ & $0.0016^{* * *}(0.0006)$ & $-0.0020^{* * *}(0.0005)$ & $0.0025^{* * *}(0.0004)$ \\
\hline $\begin{array}{l}\text { Logged market value of crop } \\
\text { products }\end{array}$ & $0.1153 * * *(0.0078)$ & $-0.1064 * * *(0.0075)$ & $0.1292 * * *(0.0079)$ & $-0.1090^{* * *}(0.0076)$ \\
\hline $\begin{array}{l}\text { Logged market value of } \\
\text { livestock products }\end{array}$ & $-0.0205^{* * *}(0.0083)$ & $0.0298 * * *(0.0083)$ & $-0.0327^{* * *}(0.0084)$ & $0.0352 * * *(0.0077)$ \\
\hline Time dummy if year $=1992$ & $-0.0013(0.0323)$ & $0.0076(0.0253)$ & $0.0210(0.0712)$ & $-0.0011(0.0446)$ \\
\hline Time dummy if year $=1997$ & $-0.0476(0.0594)$ & $0.0223(0.0724)$ & $-0.0597(0.0625)$ & $0.0350(0.0952)$ \\
\hline Time dummy if year $=2002$ & $-0.1015(0.1553)$ & $0.0323(0.1503)$ & $-0.1139(0.2022)$ & $0.0341(0.2043)$ \\
\hline Time dummy if year $=2007$ & $-0.2280 *(0.1398)$ & $0.1263(0.3435)$ & $-0.2393 *(0.1535)$ & $0.1346(0.3892)$ \\
\hline Log-likelihood & $\begin{array}{l}\text { Null: } \\
-823.8861\end{array}$ & & $\begin{array}{l}\text { Alternative: } \\
-812.0943\end{array}$ & \\
\hline Likelihood Ratio test & $p<0.01$ & & & \\
\hline
\end{tabular}

Robust standard errors are in parentheses; $* p<0.1, * * p<0.05$, and $* * * p<0.01$, respectively

become more severe. However, more land is converted to crop from pasture use when winter moisture deviations increase, probably because winter moisture allows early planting. However, for short time rainfall conditions, we find that the probability of crop land declines when precipitation increases in summer, suggesting excess rainfall can be harmful to crop growing. In contrast, the probability of pasture land responds positively to precipitation and increases with spring, summer and winter precipitation. In interpreting these results, we do think it is important to look at how the individual items influence land use but no single item would act on its own. For example, the Palmer drought index would also vary when temperatures and precipitation are altered. 
Market values of crop and livestock products are two other critical factors. When crop production becomes less profitable relative to livestock production, farmers move land from crop to pasture. The opposite occurs when crop production becomes more profitable.

It is worth noting that our results with and without controlling for regional differences do not affect the direction of the climate effects. However, the likelihood-ratio test indicates that the model with regional effects performs better $(p<0.01)$. We also examine results for each census time period to provide an alternative robustness test for model specification (following Schlenker et al. 2005, 2006; Schlenker and Roberts 2006). Test results show that there is little change in estimated coefficients. In other words, our estimations for different periods are consistent indicating that model specification is robust.

\subsection{Cattle stocking rate and climate}

The relationship between climate variables and stocking rate from OLS and Quantile regressions are shown in Table 4. Quantile regression models are used because they provide estimates approximating either the median or other quantiles of the livestock stocking rate rather than the conditional mean estimates.

Moisture is an important factor in explaining stocking rate (Meyer et al. 2008). Results in Table 4 show effects of summer precipitation are significant and generally indicate that stocking rate initially increases and then decreases with summer moisture. Nationally, the peak of stocking rate occurs when precipitation is at $14 \mathrm{in}$.; however, the maximum stocking rate changes across regions because vegetation varies in composition and production largely due to changes in precipitation (Redfearn and Bidwell 2011). We also find higher precipitation intensity has a negative effect on stocking rate as more intense rains tend to run off rapidly and thus do not effectively support forage yields and supply.

We included the temperature-humidity index (THI) in the analysis because it is a commonly used index in livestock production studies (Mader et al. 2009; Bohmanova et al. 2007). We find that the summer THI index is significant and negatively affects stocking rate suggesting a higher summer THI index is harmful to livestock productivity, consistent with Hahn et al. (2005) and Nienaber and Hahn (2007).

Our results also show that some regional dummy variables (e.g., Corn Belt, Lake States, North East, South Central and Southeast) are statistically significant and have positive effects relative to the Pacific Southwest (PSW). When controlling all other variables, these five regions have a higher stocking rate than the reference region.

We also find that stocking rate increases as the market value of livestock products increase. Assuming that the change in livestock production is relatively larger than the change in price due to inelastic demand, farmers are likely to raise more animals if livestock products become more profitable.

\section{Climate projections and economic impacts assessment}

Now, we examine the effects of projected climate change on land use shares and stocking rate. In addition, we evaluate the economic losses (gains) of farms adapting to climate change via land use change. 
Table 4 Regression results for cattle stocking rate

\begin{tabular}{|c|c|c|c|c|}
\hline \multirow[t]{2}{*}{ Variable } & \multirow[t]{2}{*}{ OLS } & \multicolumn{3}{|l|}{ Quantile Regression } \\
\hline & & $25 \%$ & $50 \%$ & $75 \%$ \\
\hline Corn Belt (CB) & $0.3189^{* * *}(0.0917)$ & $0.1270 * * *(0.0492)$ & $0.2098 * * *(0.0691)$ & $0.2858 * * *(0.0898)$ \\
\hline Great Plains (GP) & $0.0457(0.0977)$ & $0.0060(0.0487)$ & $-0.0169(0.0722)$ & $-0.0218(0.0842)$ \\
\hline Lake States (LS) & $0.5891 * * *(0.1305)$ & $0.1801^{* * *}(0.0589)$ & $0.3542 * * *(0.0818)$ & $0.5898 * * *(0.0888)$ \\
\hline North East (NE) & $0.3891 * * *(0.1013)$ & $0.0804 * * *(0.0534)$ & $0.2612 * * *(0.0950)$ & $0.5257 * * *(0.0941)$ \\
\hline $\begin{array}{l}\text { Rocky Mountains } \\
\text { (RM) }\end{array}$ & $0.1272 *(0.0759)$ & $0.0317(0.0411)$ & $0.0634(0.0618)$ & $-0.0119(0.0631)$ \\
\hline $\begin{array}{l}\text { Pacific Northwest } \\
\text { (PNW) }\end{array}$ & $0.0120(0.0520)$ & $0.0421(0.0383)$ & $0.0429(0.0574)$ & $-0.0395(0.0572)$ \\
\hline South Central (SC) & $0.1718 * *(0.0816)$ & $-0.0197(0.0510)$ & $0.0836(0.0630)$ & $0.0357(0.0720)$ \\
\hline South East (SE) & $0.2309^{* * *}(0.0738)$ & $0.0851 *(0.0445)$ & $0.1297 * *(0.0628)$ & $0.0515(0.0672)$ \\
\hline South West (SW) & $0.1326(0.0933)$ & $-0.0361(0.0494)$ & $0.0212(0.0707)$ & $0.0115(0.0878)$ \\
\hline Spring precipitation & $-0.0111(0.0092)$ & $0.0028(0.0064)$ & $-0.0003(0.0065)$ & $0.0044(0.0107)$ \\
\hline $\begin{array}{l}\text { Squared spring } \\
\text { precipitation }\end{array}$ & $0.0004(0.0003)$ & $-0.0001(0.0003)$ & $0.0001(0.0003)$ & $-0.0001(0.0004)$ \\
\hline Summer precipitation & $0.0202 * * *(0.0075)$ & $0.0178^{* * *}(0.0051)$ & $0.0212 * * *(0.0053)$ & $0.0205 * *(0.0082)$ \\
\hline $\begin{array}{l}\text { Squared summer } \\
\text { precipitation }\end{array}$ & $-0.0007 * * *(0.0002)$ & $-0.0005^{* * *}(0.0002)$ & $-0.0006 * * *(0.0002)$ & $-0.0005 *(0.0003)$ \\
\hline Winter precipitation & $0.0187 * *(0.0074)$ & $0.0073(0.0048)$ & $0.0064(0.0049)$ & $0.0057(0.0063)$ \\
\hline $\begin{array}{l}\text { Squared winter } \\
\text { precipitation }\end{array}$ & $-0.0002(0.0002)$ & $-0.0001(0.0002)$ & $0.0000(0.0001)$ & $0.0001(0.0002)$ \\
\hline $\begin{array}{l}\text { Spring Palmer } \\
\text { drought index }\end{array}$ & $0.0163(0.0130)$ & $0.0056(0.0082)$ & $0.0113(0.0073)$ & $0.0147(0.0108)$ \\
\hline $\begin{array}{r}\text { Summer Palmer } \\
\text { drought index }\end{array}$ & $0.0041(0.0108)$ & $-0.0085(0.0052)$ & $-0.0104 * *(0.0053)$ & $-0.0181 * *(0.0074)$ \\
\hline $\begin{array}{l}\text { Winter Palmer } \\
\text { drought index }\end{array}$ & $-0.0147(0.0167)$ & $0.0000(0.0076)$ & $-0.0023(0.0067)$ & $0.0029(0.0093)$ \\
\hline $\begin{array}{l}\text { Precipitation intensity } \\
\text { index }\end{array}$ & $-0.2155^{*}(0.1265)$ & $-0.1184(0.0943)$ & $-0.1083(0.0884)$ & $\begin{array}{l}-0.2501^{*} \\
\quad(0.1313)\end{array}$ \\
\hline $\begin{array}{l}\text { Number of hot days } \\
\text { with temp }>90^{\circ} \mathrm{F}\end{array}$ & $-0.0006(0.0006)$ & $0.0000(0.0004)$ & $-0.0003(0.0004)$ & $-0.0006(0.0005)$ \\
\hline $\begin{array}{l}\text { Logged market value } \\
\text { of crop products }\end{array}$ & $-0.0475 * * *(0.0104)$ & $-0.0112 * *(0.0062)$ & $-0.0118 *(0.0061)$ & $-0.0135 *(0.0079)$ \\
\hline $\begin{array}{l}\text { Logged market value } \\
\text { of livestock products }\end{array}$ & $0.0513 * * *(0.0146)$ & $0.0212 * * *(0.0077)$ & $0.0413^{* * *}(0.0067)$ & $0.0463 * * *(0.0087)$ \\
\hline $\begin{array}{l}\text { Summer temperature- } \\
\text { humidity index }\end{array}$ & $-0.0111 * *(0.0061)$ & $0.0007(0.0041)$ & $-0.0059(0.0040)$ & $-0.0052(0.0061)$ \\
\hline $\begin{array}{l}\text { Winter temperature- } \\
\text { humidity index }\end{array}$ & $-0.0114(0.0358)$ & $-0.0249(0.0288)$ & $-0.0219(0.0435)$ & $-0.0031(0.0454)$ \\
\hline Constant & $0.1822(2.2170)$ & $1.0242(1.7638)$ & $1.0524(2.6224)$ & $-0.1268(2.7351)$ \\
\hline R-squared & 0.2683 & 0.2089 & 0.2266 & 0.3077 \\
\hline
\end{tabular}

The robust standard error for the OLS model and the bootstrap standard error for the Quantile regression are in parentheses; $* p<0.1, * * p<0.05$, and $* * * p<0.01$, respectively

\subsection{Adaptation projection under future climate change}

To do the projection, we use the regression equation (with regional effects) estimated from historical data with climate variables derived from several climate projections. We utilize 
four General Circulation Models (GCMs) used in the IPCC (2007a) under the A1B scenario from the Special Report to Emission Scenarios (SRES). The GCMs include,

- The Coupled Global Climate Model, version 3.1(CGCM3.1)

- The Geophysical Fluid Dynamics Laboratory Coupled Model, version 2.0 (GFDL: CM2.0) and version 2.1 (GFDL: CM2.1)

- The Meteorological Research Institute (MRI) coupled general circulation model, version 2.3 (MRI: CGCM2.3)

Through the IPCC Data Distribution Center, we obtained the projected changes in temperature and precipitation for three periods, 2010-2039, 2040-2069 and 2070-2099 for each climate model. We only use the climate projections under the A1B emission scenario because it is near the middle of the SRES range (Nakićenović and Swart 2000; IPCC 2007a).

We use the average of observed temperature and precipitation in 1961-1990 as the baseline data. In forming the projections, we draw monthly mean temperature and monthly total precipitation and average them to generate seasonal temperature and precipitation data. We then predict land use probabilities using baseline climate data and alternative projected climate data.

Table 5 presents the aggregated marginal effects on the probability of farmland use shares and livestock stocking rate at the national level. In the baseline, the probability of land use for crop and pasture usage is $60 \%$ and $29 \%$, respectively. By the end of $21 \mathrm{st}$ century, the likelihood of crop land use declines to $50 \%$ under GFDL: CM2.1 and to $57 \%$ under MRI: CGCM2.3. In contrast, the probability of pasture use increases to $43 \%$ under GFDL: CM2.1 and $32 \%$ under MRI: CGCM2.3. Averaged across four GCMs and relative

Table 5 Probability of land use adaptation under climate change

\begin{tabular}{|c|c|c|c|c|}
\hline & 1961-1990 & 2010-2039 & 2040-2069 & 2070-2099 \\
\hline & Base & & CGCM3.1 & \\
\hline Crop & $0.60(0.19)$ & $0.55(0.18)$ & $0.54(0.18)$ & $0.53(0.19)$ \\
\hline Pasture & $0.29(0.19)$ & $0.35(0.22)$ & $0.36(0.22)$ & $0.37(0.23)$ \\
\hline \multirow[t]{2}{*}{ Stocking rate } & $0.49(0.22)$ & $0.49(0.22)$ & $0.46(0.22)$ & $0.44(0.22)$ \\
\hline & Base & & GFDL: CM2.0 & \\
\hline Crop & $0.60(0.19)$ & $0.55(0.17)$ & $0.53(0.18)$ & $0.52(0.18)$ \\
\hline Pasture & $0.29(0.19)$ & $0.38(0.23)$ & $0.39(0.24)$ & $0.41(0.24)$ \\
\hline \multirow[t]{2}{*}{ Stocking rate } & $0.49(0.22)$ & $0.53(0.23)$ & $0.48(0.24)$ & $0.45(0.24)$ \\
\hline & Base & & GFDL: CM2.1 & \\
\hline Crop & $0.60(0.19)$ & $0.54(0.18)$ & $0.50(0.19)$ & $0.50(0.18)$ \\
\hline Pasture & $0.29(0.19)$ & $0.39(0.23)$ & $0.41(0.24)$ & $0.43(0.24)$ \\
\hline \multirow[t]{2}{*}{ Stocking rate } & $0.49(0.22)$ & $0.50(0.22)$ & $0.46(0.23)$ & $0.43(0.23)$ \\
\hline & Base & & MRI: CGCM2.3 & \\
\hline Crop & $0.60(0.19)$ & $0.59(0.20)$ & $0.57(0.20)$ & $0.57(0.21)$ \\
\hline Pasture & $0.29(0.19)$ & $0.31(0.21)$ & $0.32(0.21)$ & $0.32(0.21)$ \\
\hline Stocking rate & $0.49(0.22)$ & $0.47(0.21)$ & $0.45(0.21)$ & $0.43(0.21)$ \\
\hline
\end{tabular}

Standard errors are reported in parentheses; Probabilities in this table are aggregated at the national level 
to the baseline, crop land decreases by $6 \%$ and pasture land increases by $33 \%$ by the end of this century.

In the baseline, cattle stocking rate is about 0.58 animal units per acre. By the end of this century, cattle stocking rate decreases to about 0.52 animal units per acre under both CGCM3.1 and GFDL2.0, and 0.50 animal units per acre under the other GCMs. These results suggest that farmers might adapt to the effects of a changing climate on forage supply by reducing the numbers of animals per acre.

Projected changes in land use under climate change vary across the country. Figure 2 shows regional projections of crop land use probability, suggesting that effects on cropland use are greater in the central states with declines in the north and increases in the three most southern central states. Conversely, Fig. 3 reveals a relatively greater shift to pasture land in central (followed by western) regions. Projected stocking rate decreases in the second and third time periods, and persistently decreases in the central eastern states (see Fig. 4).

These results show that there will be producer actions in the form of autonomous adaptations as climate change proceeds with land flowing from crops to pasture and

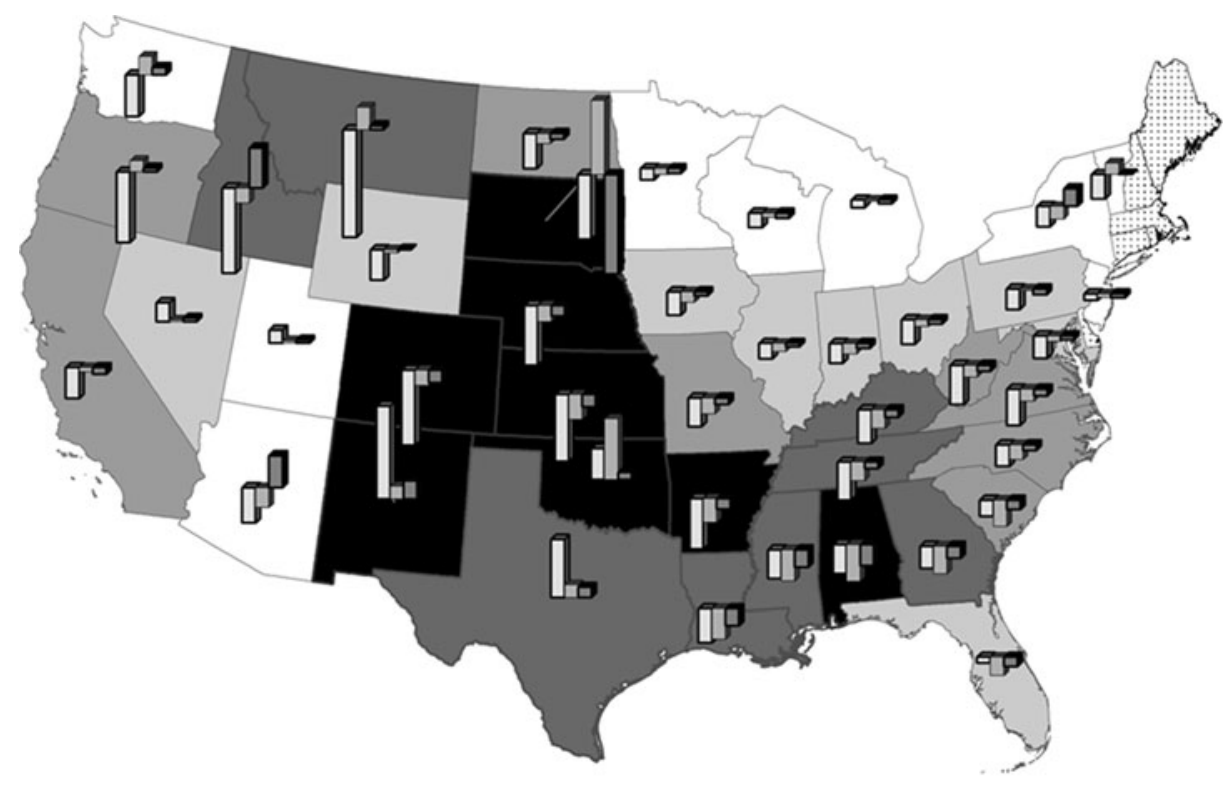

Legend

Mean absolute change in crop land probability between 2099 and base period

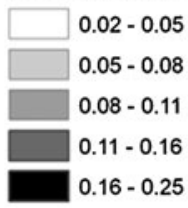

Mean crop land probabiltiy change between time periods

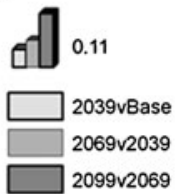

States with no data

Fig. 2 Change in crop land probability. Absolute change in mean crop land probability (state map) and difference in mean crop land probability between time periods (bar graphs) 


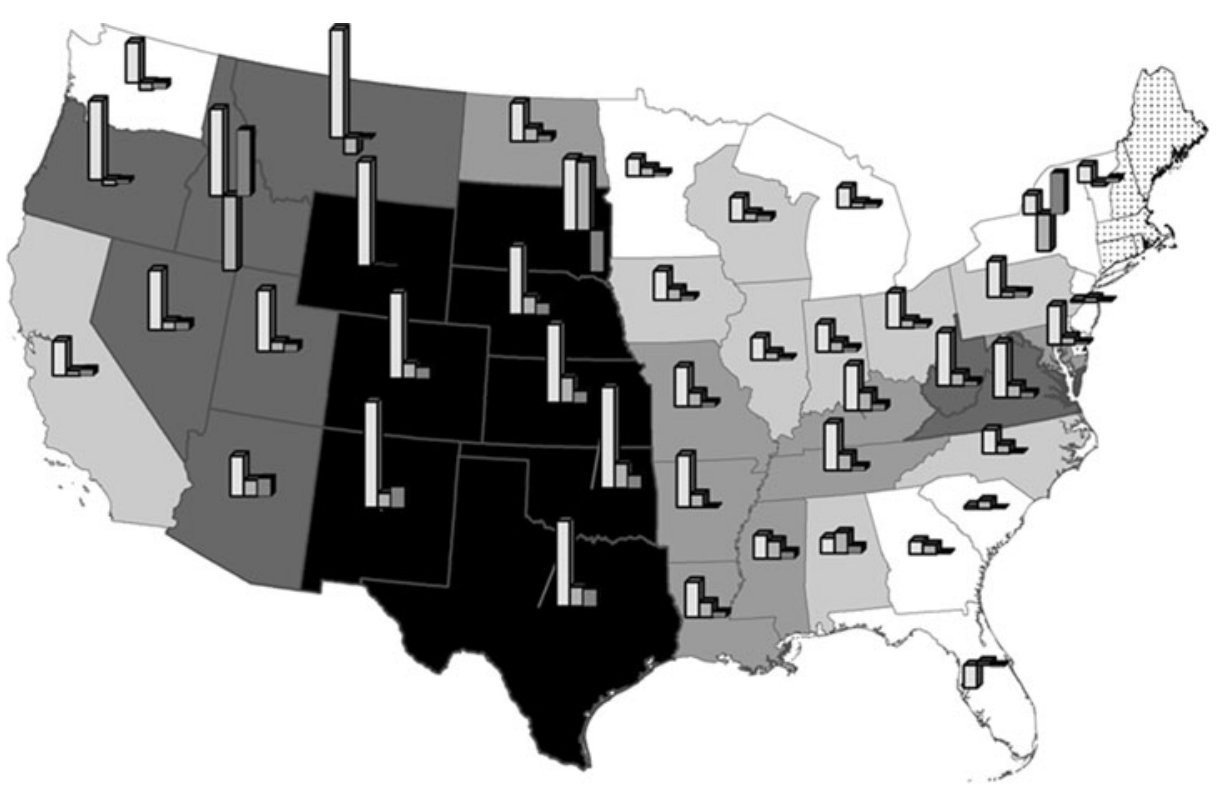

\section{Legend}

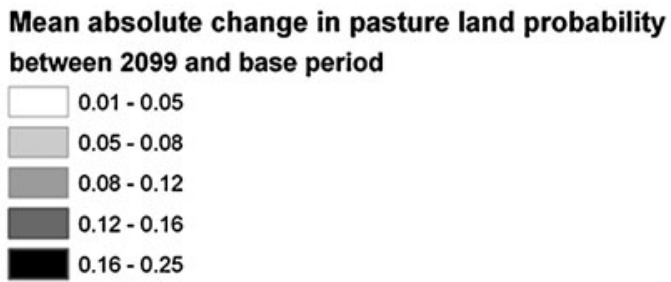

Mean pasture probabiltiy change between time periods

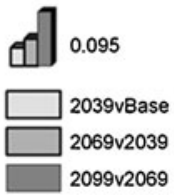

States with no data

Fig. 3 Change in pasture land probability. Absolute change in mean pasture land probability (state map) and difference in mean pasture land probability between time periods (bar graphs)

stocking rates being reduced. This also suggests that public grazing allotments, largely in the U.S. west, may need to be reduced in some areas. More generally, producers and interested stakeholders likely need to monitor forage conditions for evidence of overgrazing with attention paid to potential stocking rate reductions. There are implications for wildlife related to reductions/increases in carrying capacity of grazing lands coupled with an expansion of grazing land uses on former croplands. Moreover, the results suggest changes in rural incomes as land for livestock use is generally worth less than land in cropping and lower stocking rates also would lower incomes.

\subsection{Economic impact assessment}

Under climate change, we find that more land is transferred from crop to livestock production use and the livestock stocking rate declines. To evaluate the associated economic losses (gains) to crop producers (livestock producers), we use crop and pasture land values in 2007 from USDA NASS, which is assumed to be constant over 


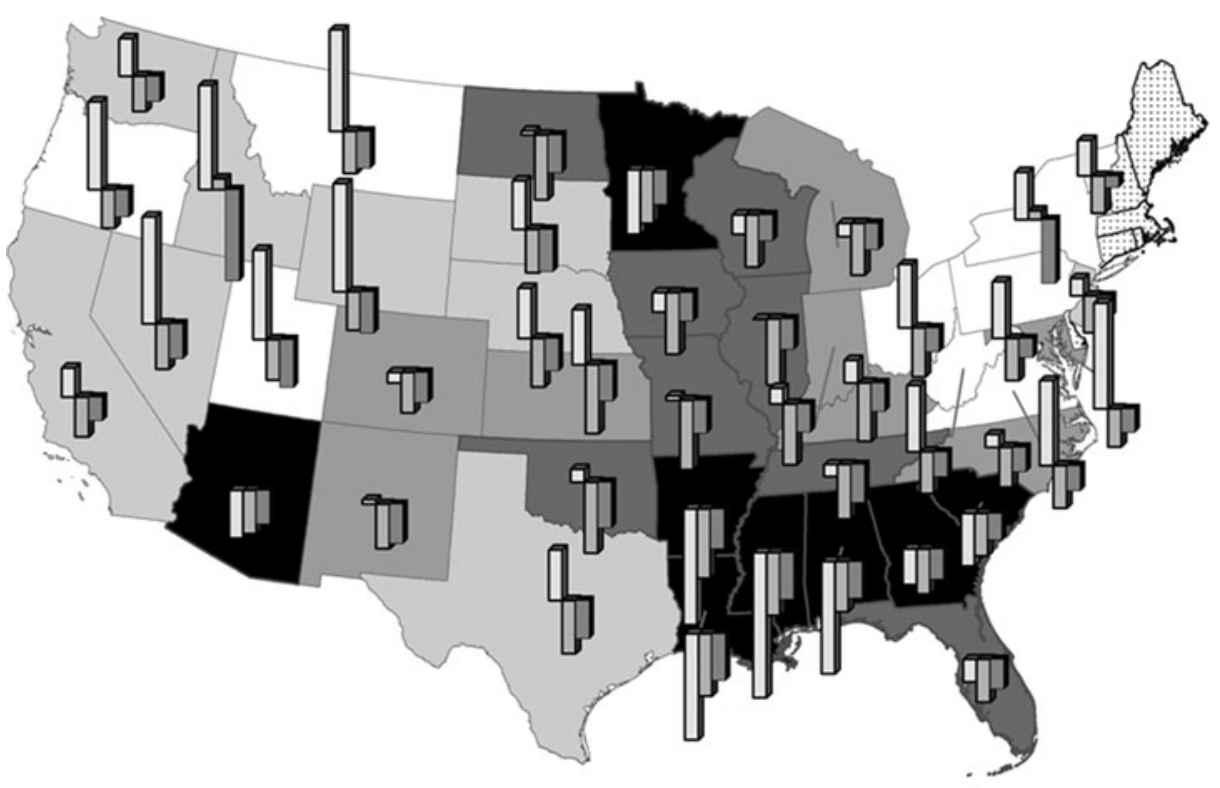

\section{Legend}

Mean absolute change in stocking rate between 2099 and base period

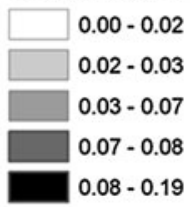

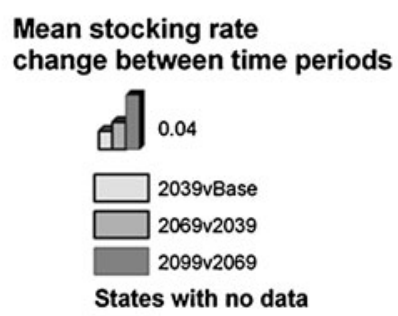

Mean stocking rate$$
\text { riods }
$$

湿国

Fig. 4 Change in stocking rate. Absolute change in mean stocking rate (state map) and difference in mean stocking rate between time periods (bar graphs)

time and all other variables are controlled, ${ }^{5}$ and the projected changes in land use probability.

On average across four GCMs, the economic loss of U.S crop producers is 11, 15 and 14 million dollars in 2007 value in 2039, 2069 and 2099, respectively. On the contrary, U.S. livestock producers will gain 20, 26 and 29 million dollars in 2007 value by 2039, 2069 and 2099, respectively.

\section{Conclusions}

In this paper, we analyzed farmers' adaptation to climate change through,

- Changes between crop and pasture land use

- Adjustments of livestock stocking rate

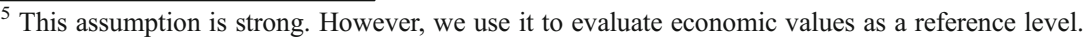


Based on econometric estimations, we find that climate variables explain changes in land use shares and stocking rate. Particularly,

- The Summer Palmer drought index and number of hot days with temperature higher than $90^{\circ} \mathrm{F}$ are important factors for explaining land use changes and livestock stocking rate changes.

- Land use switches from cropping to pasture as summer temperatures increase.

- Stocking rate declines are associated with a rising temperature-humidity index during the summer.

Using temperature and precipitation data from four GCMs, our projections suggest that climate change will induce land use change from cropping to pasture and stocking rate will decline particularly in the central and the southeast regions.

By adapting to future climate change, the annual economic losses to crop producers are around 14 million dollars and livestock producers will gain 29 million dollars by the end of this century. Like land use change, economic impacts of climate change on crop and pasture land change will vary across regions with some regions losing and others gaining. Therefore, farm programs or agriculture subsidy policies related to climate change adaption should consider these welfare changes.

All results in this paper are based on the assumption that price is taken as given. However, there will likely be a price response to productivity changes that will affect profits and land use choices. A natural extension of this research is to apply an economic model with endogenous prices. In addition, this study isolates effects of climate change on land use, while land use could also contribute to climate change (Mendelsohn and Dinar 2009). The interaction between climate change and land use should also be addressed in the future.

\section{Appendix}

Table 6 Estimated coefficients from the FMLOGIT with and without regional effects

\begin{tabular}{|c|c|c|c|c|}
\hline & \multicolumn{2}{|c|}{ Model with Market Region Effects } & \multicolumn{2}{|c|}{ Model without Market Region Effects } \\
\hline & Crop Land & Pasture Land & Crop Land & Pasture Land \\
\hline Corn Belt (CB) & $\begin{array}{c}0.8770 * \\
(0.4943)\end{array}$ & $\begin{array}{c}-0.5287 \\
(0.4886)\end{array}$ & & \\
\hline Great Plains (GP) & $\begin{array}{l}1.6807 * * \\
(0.5477)\end{array}$ & $\begin{array}{c}0.7098 \\
(0.5213)\end{array}$ & & \\
\hline Lake States (LS) & $\begin{array}{c}0.0759 \\
(0.5138)\end{array}$ & $\begin{array}{l}-1.6252^{* * *} \\
(0.5128)\end{array}$ & & \\
\hline North East (NE) & $\begin{array}{c}-0.0896 \\
(0.5027)\end{array}$ & $\begin{array}{c}-1.3123 * * \\
(0.5085)\end{array}$ & & \\
\hline Rocky Mountains (RM) & $\begin{array}{c}0.0894 \\
(0.4679)\end{array}$ & $\begin{array}{c}-0.1545 \\
(0.4278)\end{array}$ & & \\
\hline Pacific Northwest (PNW) & $\begin{array}{c}0.6083 \\
(0.4875)\end{array}$ & $\begin{array}{c}0.1634 \\
(0.3720)\end{array}$ & & \\
\hline South Central (SC) & $\begin{array}{c}0.8044 * \\
(0.4820)\end{array}$ & $\begin{array}{c}-0.1573 \\
(0.4347)\end{array}$ & & \\
\hline
\end{tabular}


Table 6 (continued)

\begin{tabular}{|c|c|c|c|c|}
\hline & \multicolumn{2}{|c|}{ Model with Market Region Effects } & \multicolumn{2}{|c|}{ Model without Market Region Effects } \\
\hline & Crop Land & Pasture Land & Crop Land & Pasture Land \\
\hline South East (SE) & $\begin{array}{l}-0.1769 \\
(0.4679)\end{array}$ & $\begin{array}{c}-0.8952 * * \\
(0.4401)\end{array}$ & & \\
\hline South West (SW) & $\begin{array}{l}-0.0177 \\
(0.5086)\end{array}$ & $\begin{array}{c}-0.0801 \\
(0.4842)\end{array}$ & & \\
\hline Spring precipitation & $\begin{array}{l}0.0651 * * \\
(0.0280)\end{array}$ & $\begin{array}{c}0.0030 \\
(0.0325)\end{array}$ & $\begin{array}{l}0.0643 * * \\
(0.0287)\end{array}$ & $\begin{array}{c}-0.0404 \\
(0.0372)\end{array}$ \\
\hline Squared spring precipitation & $\begin{array}{c}-0.0011 \\
(0.0009)\end{array}$ & $\begin{array}{c}0.0008 \\
(0.0009)\end{array}$ & $\begin{array}{c}0.0000 \\
(0.0009)\end{array}$ & $\begin{array}{l}0.0027 * * \\
(0.0012)\end{array}$ \\
\hline Summer precipitation & $\begin{array}{c}-0.0776^{* *} \\
(0.0380)\end{array}$ & $\begin{array}{l}-0.2520 * * * \\
(0.0533)\end{array}$ & $\begin{array}{l}-0.1146 * * * \\
(0.0417)\end{array}$ & $\begin{array}{l}-0.3616^{* * *} \\
(0.0480)\end{array}$ \\
\hline Squared summer precipitation & $\begin{array}{l}0.0030 * * \\
(0.0014)\end{array}$ & $\begin{array}{l}0.0084 * * * \\
(0.0017)\end{array}$ & $\begin{array}{l}0.0042 * * \\
(0.0017)\end{array}$ & $\begin{array}{l}0.0109 * * * \\
(0.0017)\end{array}$ \\
\hline Winter precipitation & $\begin{array}{c}0.0132 \\
(0.0218)\end{array}$ & $\begin{array}{l}-0.0796 * * * \\
(0.0302)\end{array}$ & $\begin{array}{c}-0.0244 \\
(0.0272)\end{array}$ & $\begin{array}{l}-0.1121^{* * *} \\
(0.0364)\end{array}$ \\
\hline Squared winter precipitation & $\begin{array}{c}-0.0003 \\
(0.0006)\end{array}$ & $\begin{array}{c}0.0014 * \\
(0.0007)\end{array}$ & $\begin{array}{c}0.0011 \\
(0.0008)\end{array}$ & $\begin{array}{l}0.0028 * * * \\
(0.0010)\end{array}$ \\
\hline Spring temperature & $\begin{array}{c}-0.0285 \\
(0.0597)\end{array}$ & $\begin{array}{l}-0.0670 \\
(0.0706)\end{array}$ & $\begin{array}{c}-0.1604 * * \\
(0.0657)\end{array}$ & $\begin{array}{c}-0.0832 \\
(0.0916)\end{array}$ \\
\hline Squared spring temperature & $\begin{array}{c}0.0000 \\
(0.0006)\end{array}$ & $\begin{array}{c}0.0012 * \\
(0.0007)\end{array}$ & $\begin{array}{l}0.0017 * * \\
(0.0007)\end{array}$ & $\begin{array}{l}0.0020 * * \\
(0.0009)\end{array}$ \\
\hline Summer temperature & $\begin{array}{l}0.4031 * * \\
(0.1847)\end{array}$ & $\begin{array}{l}1.0863 * * * \\
(0.2201)\end{array}$ & $\begin{array}{l}0.5797 * * \\
(0.2244)\end{array}$ & $\begin{array}{l}1.2699 * * * \\
(0.2409)\end{array}$ \\
\hline Squared summer temperature & $\begin{array}{c}-0.0026^{*} \\
(0.0013)\end{array}$ & $\begin{array}{l}-0.0080 * * * \\
(0.0016)\end{array}$ & $\begin{array}{c}-0.0037 * * \\
(0.0017)\end{array}$ & $\begin{array}{l}-0.0094 * * * \\
(0.0018)\end{array}$ \\
\hline Winter temperature & $\begin{array}{c}-0.0374 * \\
(0.0216)\end{array}$ & $\begin{array}{r}-0.0498 \\
(0.0319)\end{array}$ & $\begin{array}{l}-0.0025 \\
(0.0245)\end{array}$ & $\begin{array}{c}-0.0318 \\
(0.0318)\end{array}$ \\
\hline Squared winter temperature & $\begin{array}{c}0.0002 \\
(0.0003)\end{array}$ & $\begin{array}{c}0.0004 \\
(0.0006)\end{array}$ & $\begin{array}{c}-0.0009 * * \\
(0.0004)\end{array}$ & $\begin{array}{c}-0.0002 \\
(0.0006)\end{array}$ \\
\hline Spring Palmer drought index & $\begin{array}{r}-0.0045 \\
(0.0300)\end{array}$ & $\begin{array}{c}0.0077 \\
(0.0464)\end{array}$ & $\begin{array}{c}-0.0556^{*} \\
(0.0323)\end{array}$ & $\begin{array}{c}-0.0878 * \\
(0.0458)\end{array}$ \\
\hline Summer Palmer drought index & $\begin{array}{c}-0.0414 \\
(0.0311)\end{array}$ & $\begin{array}{c}0.0687^{*} \\
(0.0369)\end{array}$ & $\begin{array}{c}0.0002 \\
(0.0310)\end{array}$ & $\begin{array}{l}0.2112 * * * \\
(0.0397)\end{array}$ \\
\hline Winter Palmer drought index & $\begin{array}{c}-0.0097 \\
(0.0266)\end{array}$ & $\begin{array}{r}-0.0602 \\
(0.0427)\end{array}$ & $\begin{array}{c}0.0302 \\
(0.0263)\end{array}$ & $\begin{array}{r}-0.0451 \\
(0.0424)\end{array}$ \\
\hline Precipitation intensity index & $\begin{array}{c}0.3441 \\
(0.2607)\end{array}$ & $\begin{array}{c}0.4279 \\
(0.3194)\end{array}$ & $\begin{array}{c}0.2019 \\
(0.2487)\end{array}$ & $\begin{array}{l}-0.2013 \\
(0.3181)\end{array}$ \\
\hline $\begin{array}{l}\text { Number of hot days with } \\
\text { temp }>90^{\circ} \mathrm{F}\end{array}$ & $\begin{array}{r}-0.0035 \\
(0.0028)\end{array}$ & $\begin{array}{c}0.0048 \\
(0.0033)\end{array}$ & $\begin{array}{c}0.0013 \\
(0.0036)\end{array}$ & $\begin{array}{l}0.0131 * * * \\
(0.0038)\end{array}$ \\
\hline $\begin{array}{l}\text { Logged market value of crop } \\
\text { products }\end{array}$ & $\begin{array}{l}0.2728 * * * \\
(0.0390)\end{array}$ & $\begin{array}{l}-0.2900 * * * \\
(0.0467)\end{array}$ & $\begin{array}{l}0.3979 * * * \\
(0.0398)\end{array}$ & $\begin{array}{l}-0.1954 * * * \\
(0.0460)\end{array}$ \\
\hline $\begin{array}{l}\text { Logged market value of livestock } \\
\text { products }\end{array}$ & $\begin{array}{c}0.0543 \\
(0.0411)\end{array}$ & $\begin{array}{l}0.1927 * * * \\
(0.0513)\end{array}$ & $\begin{array}{c}-0.0317 \\
(0.0463)\end{array}$ & $\begin{array}{l}0.1448 * * * \\
(0.0489)\end{array}$ \\
\hline
\end{tabular}


Table 6 (continued)

\begin{tabular}{|c|c|c|c|c|}
\hline & \multicolumn{2}{|c|}{ Model with Market Region Effects } & \multicolumn{2}{|c|}{ Model without Market Region Effects } \\
\hline & Crop Land & Pasture Land & Crop Land & Pasture Land \\
\hline Time dummy if year $=1992$ & $\begin{array}{c}0.0584 \\
(0.0850)\end{array}$ & $\begin{array}{c}0.0868 \\
(0.1101)\end{array}$ & $\begin{array}{l}0.2266^{* *} \\
(0.0876)\end{array}$ & $\begin{array}{c}0.1882 \\
(0.1168)\end{array}$ \\
\hline Time dummy if year $=1997$ & $\begin{array}{c}-0.3030 * * * \\
(0.0850)\end{array}$ & $\begin{array}{c}-0.1464 \\
(0.1208)\end{array}$ & $\begin{array}{l}-0.3119 * * * \\
(0.0983)\end{array}$ & $\begin{array}{r}-0.0920 \\
(0.1411)\end{array}$ \\
\hline Time dummy if year $=2002$ & $\begin{array}{c}-0.7205 * * * \\
(0.0770)\end{array}$ & $\begin{array}{l}-0.4338 * * * \\
(0.1278)\end{array}$ & $\begin{array}{l}-0.7964 * * * \\
(0.0967)\end{array}$ & $\begin{array}{l}-0.4792 * * * \\
(0.1387)\end{array}$ \\
\hline Time dummy if year $=2007$ & $\begin{array}{c}-1.1986^{* * *} \\
(0.0862)\end{array}$ & $\begin{array}{c}-0.3703^{* * *} \\
(0.1349)\end{array}$ & $\begin{array}{c}-1.2249 \text { *** } \\
(0.0926)\end{array}$ & $\begin{array}{c}-0.3463 * * * \\
(0.1325)\end{array}$ \\
\hline Constant & $\begin{array}{c}-15.6049 * * \\
(6.2311)\end{array}$ & $\begin{array}{c}-30.7616^{* * *} \\
(7.1833)\end{array}$ & $\begin{array}{c}-19.6509 * * * \\
(7.4436)\end{array}$ & $\begin{array}{c}-37.6677 * * * \\
(7.4967)\end{array}$ \\
\hline
\end{tabular}

Robust standard errors are in parentheses; ${ }^{*} p<0.1,{ }^{*} p<0.05$, and $* * * p<0.01$, respectively

\section{References}

Adams RM, Rosenzweig C, Peart RM, Ritchie JT, McCall BA, Glyer JD, Curry RB, Jones JW, Boote KJ, Allen LH (1990) Global climate change and U.S. agriculture. Nature 345:219-224. doi:10.1038/345219a0

Bohmanova J, Misztal I, Cole JB (2007) Temperature-humidity indices as indicators of milk production losses due to heat stress. J Dairy Sci 90:1947-1956

U.S. Climate Change Science Program (2008) The effects of climate change on agriculture, land resources, water resources, and biodiversity in the United States. A report by the U.S. climate change science program and the subcommittee on global change research

Dikmen S, Hansen PJ (2009) Is the temperature-humidity index the best indicator of heat stress in lactating dairy cows in a subtropical environment? J Dairy Sci 92:109-116

Gourieroux C, Monfort A, Trognon A (1984) Pseudo maximum likelihood methods: theory. Econometrica 52 (3):681-700

Hahn GL, Brown-Brand T, Eigenberg RA, Gaughan JB, Mader TL, and Nienaber JA (2005) Climate change and livestock: challenges and adaptive responses of animals and production systems. Paper presented at the 17th international conference on biometeorology, Garmisch-Partenkirchen, Bavaria, Germany

Herrero M, Thornton PK, Kruska R, Reid RS (2008) Systems dynamics and the spatial distribution of methane emissions from African domestic ruminants to 2030. Agr Ecosyst Environ 126:122-137

Hoffmann I (2010) Climate change and the characterization, breeding and conservation of animal genetic resources. Anim Genet 41(s1):32-46

Holden NM, Brereton AJ (2002) An assessment of the potential impact of climate change on grass yield in Ireland over the next 100 years. Ir J Agr Food Res 41:213-226

IPCC (2007a) Climate Change 2007: the physical science basis. In: Solomon S, Qin D, Manning M, Chen Z, Marquis M, Averyt KB, Tignor M, Miller HL(eds) Cambridge University Press, Cambridge and New York

IPCC (2007b) Climate change 2007: impacts, adaptation and vulnerability. In: Canziani OF, Palutikof JP, van der Linden PJ and Hanson CE (eds) Cambridge University Press, Cambridge, and New York

Jones PG, Thornton PK (2009) Croppers to livestock keepers: livelihood transitions to 2050 in Africa due to climate change. Environ Sci Pol 12:427-437

Koch SF (2010) Fractional multinomial response models with an application to expenditure shares. Paper Prepared for Development Policy Research Unit Conference held in Johannesburg, South Africa, October 27-29

Mader TL, Frank KL, Harrington JA, Hahn G, Nienaber JA (2009) Potential climate change effects on warmseason livestock production in the Great Plains. Clim Chang 97:529-541

McCarl BA (2007) Adaptation options for agriculture, forestry and fisheries. http://unfccc.int/files/ cooperation_and_support/financial_mechanism/application/pdf/mccarl.pdf. Cited 22 March 2012 
Mendelsohn R, Dinar A (2009) Land use and climate change interactions. Ann Rev Resource Econom 1:309332

Meyer TL, Adams DC, Klopfenstein TJ, Volesky JD, Stalker LA, Funston RN (2008) Estimating livestock forage demand: defining the Animal Unit (AU). Western section. Amer Anima Soc Anima Sci Proc 59:213-216

Mullahy J (2010) Multivariate fractional regression estimation of econometric share models. NBER Working Paper No. 16354. http://www.nber.org/papers/w16354. Cited 22 March 2012

Mullahy J, Robert SA (2010) No time to lose: time constraints and physical activity in the production of health. Rev Econ Househ 8:409-432

Nakićenović N, Swart R (2000) Special report on emissions scenarios. Cambridge University Press, Cambridge

Neilson R, Pitelka L, Solomon A, Nathan R, Midgley G et al (2005) Forecasting regional to global plant migration in response to climate change. Bioscience 55:749-759

Nienaber JA, Hahn GL (2007) Livestock production system management responses to thermal challenges. Int J Biometeorol 52:149-157

Papke LE, Wooldridge JM (1996) Econometric methods for fractional response variables with an application to 401(k) plan participation rates. J Appl Econ 11:619-632

Papke LE, Wooldridge JM (2008) Panel data methods for fractional response variables with an applicaiton to test pass rates. J Econ 145:121-133

Pratt M, Rasmussen GA (2001) Determining your stocking rate. Utah State University Cooperative Extension. http://extension.usu.edu/files/publications/publication/NR_RM_04.pdf. Cited 22 March 2012

Ramalho EA, Ramalho JS, Murteira J (2011) Alternative estimating and testing empirical strategies for fractional regression models. J Econ Surv 25:19-68

Redfearn DD, Bidwell TG (2011) Stocking rate: the key to successful livestock production. Oklahoma Cooperative Extension Service PSS-2871. http://www.nrem.iastate.edu/research/patchburn/pubs/ PSS-2871.pdf

Rose SK, McCarl BA (2008) Greenhouse gas emissions, stabilization and the inevitability of adaptation: challenges for U.S. Agriculture. Choices 23

Schlenker W, Roberts MJ (2006) Nonlinear effects of weather on corn yields. Rev Agric Econ 28:391-398

Schlenker W, Hanemann WM, Fisher AC (2005) Will U.S. Agriculture really benefit from global warming? Accounting for irrigation in the hedonic approach. Am Econ Rev 95:395-406

Schlenker W, Hanemann WM, Fisher AC (2006) The impact of global warming on U.S. Agriculture: an econometric analysis of optimal growing conditions. Rev Econ Stat 88:113-125

Seo SN (2010) Is an integrated farm more resilient against climate change? A microeconometric analysis of portfolio diversification in African agriculture. Food Policy 35:32-40

Seo SN, Mendelsohn R (2008a) Animal husbandry in Africa: climate change impacts and adaptations. Afr J Agric Res Econom 2:65-82

Seo SN, Mendelsohn R (2008b) Measuring impacts and adaptations to climate change: a structural Ricardian model of African livestock management. Agric Econ 38:151-165

Seo SN, Mendelsohn R, Dinar A, Kurukulasuriya P (2009) Adapting to climate change mosaically: an analysis of african livestock management by agro-ecological zones. The B.E. J Econ Anal Policy 2. doi:10.2202/1935-1682.1955

Seo SN, McCarl BA, Mendelsohn R (2010) From beef cattle to sheep under global warming? An analysis of adaptation by livestock species choice in South America. Ecol Econ 69:2486-2494

Ye X, Banerjee A, Pendyala RM, Pinjari AR (2005) Understanding travel time expenditures around the world: how low can travel go? Paper presented at the 84th annual meeting of the transportation research board. National Research Council, Washington, DC

Zilberman D, Liu X, Roland-Holst D, Sunding D (2004) The economics of climate change in agriculture. Mitig Adapt Strateg Glob Chang 9:365-382 